\title{
Constitution and Building of Nation-State in Malaysia
}

\author{
Nazri Muslim ${ }^{1}$, Wan Zulkifli Wan Hassan ${ }^{1} \&$ Khairul Hamimah Mohammad Jodi ${ }^{2}$ \\ ${ }^{1}$ Pusat Citra, Universiti Kebangsaan Malaysia, Bangi, Malaysia \\ ${ }^{2}$ Cluster of Education and Social Science, Open University Malaysia, Malaysia \\ Correspondence: Wan Zulkifli Wan Hassan, Pusat Citra, Universiti Kebangsaan Malaysia, Bangi, Malaysia. E- \\ mail: nazrim@ukm.edu.my
}

Received: June 1, 2020

Accepted: June 22, $2020 \quad$ Online Published: August 17, 2020

doi:10.5539/jpl.v13n3p122

URL: https://doi.org/10.5539/jpl.v13n3p122

\begin{abstract}
The building of a nation-state is very relevant to Malaysia in facing various challenges that take place especially in terms of the diverse cultures, languages, ethnic groups and religions. khususnya dari perspektif kepelbagaian culture, language, etnik dan religion. The building of nation-state stems from the existence of the nation and the nation produces a country. Nation-state is the formation of a country based on the process of national unity and consolidated by the bordering of certain territories as its identity. Malaysia comprising of the community of various ethnic groups has faced many challenges in the process of the building of the nation-state involving language, religion, globalisation and constitutional issues. In the context of Malaysia, the building of a nation-state refers to the people of various ethnicity who need to identify themselves with this country, speak in the national language, and support the constitution which is the highest law of the country containing the 'social contract' that needs to be understood in the effort to unite Malaysians. Thus, this article will analyse the role of the constitution as one of the main elements in the building of a nation-state in Malaysia.
\end{abstract}

Keywords: nation-state, malay, religion, constitution, ethnicity

\section{Introduction}

The effort in building a nation-state is very relevant and urgent for Malaysia to address the many challenges that come its way. The debate surrounding the building of a nation-state post-independence is the concept that is used to explain the mutual relationship between the country (ruling power) and the citizens, especially in Malaysia comprising of various ethnic groups. The development of the nation-state in Malaysia has undergone a long process. Prior to the presence of the colonisers, Malaya comprises of a dominant native society, a stable Malay government other than other ethnic groups assimilated with the Malay culture. Nonetheless, the arrival of the English colonialism with its introduction of the open door policy to immigrants from Chinese and Indians, has changed the face of Malaysia from being a monoethnic to a multiethnic country. After the independence, the concept of the building of a nation-state becomes clearer as heard in the speech of Tun Dr. Mahathir Mohamad in the Malaysian Business Council on the 29 February 1991 as he introduced Vision 2020. He maintained that the first and the most basic challenge in the effort to make Malaysia a developed country according to his own mold in 2020 is the building of the Malaysian nation that is united, who upholds the future that is shared collectively and who are loyal to the nation.

\section{The Concept of a Nation-State of Malaysia}

The building of a nation-state stems from the existence of a nation and it is birthed as an entity of a country that represents the nation. A nation produces a country. Shamsul Amri Baharuddin (2012) in discussing the concept of a nation-state, has divided the nation-state in three situations. The first situation is that a nation represents a country. The concept of a nation-state begins from a race that shapes the nation and produces a country. Thus, it will produce a nation-state. As an example, the Japanese nation forms the country of Japan.

The second situation would be the nation without a country. There are several nations without their own countries and they demand for their nations to have their own countries and to have their own autonomy. For instance, the Patani Malay in the southern part of Thailand. Patani Malays used to have a government with its own authority. However, due to colonization, Patani was handed over to Thailand wheras the people are Muslims and the culture is Malay. Thus, there is a conflict when they felt that they were not part of Thailand or the Thais who are of Thai culture and whose religion is Buddhism. In addition, there emerged among the Thai Malays, those who tried to 
free themselves from the nation-state that has been built. The same goes with the Kurdish who have set camp in the north of Iraq. This nation has successfully formed an autonomous territory of Kurdistan although the country Kurdistan has not been acknowledged in the world map.

The third condition of a nation-state would be a country without a nation. This scenario applies to a country that exists and which sovereign is endorsed, but the national identity has been somewhat vague and ambiguous. Such an existence can be referred to in the context of Malaysia. Malaysia is a country with various nations or races with every ethnic retaining their respective ethnic identity. However, this aspect is a uniqueness that can be found in Malaysia in terms of the building of the country.

Nation-state is both the concept and ideology produced from the history of the European nation that was once rife with nationalism issues, and which further caused wars between European nations and ignited a revolution. It was a shift from the monarchy system to the nation system, for example the French Revolution in 1789 which fought against the feudal regime that kickstarted an academic and political debate on the Europe nation concerning the concept of nation state (Mohamed Anwar Omar Din, 2004). What is a nation-state? Chambers' Encyclopedia (1973) defines "nation building" as a collective noun and may sefe be agreed to connect a group of people possessed of certain distinctive characteristics, real or imagined, and united certain special ties, sentimental, political or both. This group must be of substantial size ... a society united under one government in a political state. In other words, nation-state is the process of producing a new nation, which is a country of sovereignty where all of its people are brought together by certain ties of language, culture, values and others that form that nation. The main purpose of the building of the nation would be to incite the sense of loyalty and unity towards the nation.

Tun Dr. Mahathir states that Malqysian Nation means people who are able to identify themselves with the country, speak Malay Language and accept the constitution. The concept of nation-state is concluded in the final speech of Tun Dr. Mahathir Mohamad that, "Malaysia must be a country that is ethnical, integrated, living in harmony with full and fair partnership, made up of one Malaysian Nation', with political and dedication to the nation." (Lee Kam Hing, 2005) The interpretation means that all citizens of Malaysia must be regarded as Malaysians, regardless of their ethnic groups. In this matter, all the citizens must pledge their loyalty to the country and not to their respective ethnic groups. Tun Mahathir has outlined three main characteristics of nation-state, which is the people of various ethnic groups in this country must be able to identify themselves with this country; they must speak in the National Language as the National Language Policy must be ethnically neutral, which means that it is not produced to preserve the interests of an ethnic group, but for the sake of the country. Other than that, they must be supportive of the constitution, the highest law of the country containing the social contract that needs to be obeyed in the effort to unite Malaysians (Hassan Ahmad 2004). In other words, it is very important to build the Malaysian nation that is patriotic to the country and which adresses racial sentiment and feelings.

Zulhilmi Paidi and Rohani Abdul Ghani (2003) opined that nation-state is the combination of three main components, namely country, individuals and the nation. The life of the people in the country must be in unity without any separation or discrimination. The society is not distinguished based on their race or due to the differences in the belief, language, nationality, type of occupation, accommodation or anything that can lead to segregation and chaos. The citizens must also share the principle based on the same ideology. Citizens must also have the belief and full confidence towards the administrative system and the law of the country. Other than that, there are five factors that become catalytic to the building of a nation-state, which is integration, nationality, nationalism, patriotism and democracy. Therefore, it canbe stated that the effort in building the nation requires the process of uniting important elements like language, culture, politics, purpose and vision that they have agreed upon. Thus, the building of a nation-state is an ongoing process and there seems to be no end to it (Chew Fong Peng, 2006). In brief, it reflects the desire of the country to create unity, integration and national identity from the state of separation and the lack of integration (Tham Seong Chee, 1983).

\section{The History of the Building of a Malaysian Nation-State}

The formation of a nation-state in Malaysia involves a long process and historical journey. Although Malaysia has been independent for more than 60 years, what was formed was a country and not a nation-state. According to Abdul Rahman Embong (2015), when Malaysia was declared independent on 31 August 1957, a country and not a nation, is produced. The same goes when Malaysia was formed on 16 September 1963, the one that exist is the country Malaysia and the not the nation of Malaysia. Thus, Malaysia is still in the process of the formation of its nation (Mohd Syariefudin Abdullah 2014).

The building of a nation-state is not a new concept, but it has been talked about for quite some time. The concept of a nation-state is an important effect sequenced from the building of a civilization. This concept began in Europe. It started from the birth of a certain ethnic. Beginning with this concept, there emerged the concept of a nation that 
reflects a great identity and which headed towards an aspect which is a country. According to Abdul Rahman Embong (2015), the concept of a nation-state in Europe began when there is a group of nations that opposed the feudal pwoer and the process of the formation of a new system named capitalist. The success of the capitalist enabled them to be in power and to form a modern country where the entity of the country has a border and there are some nations with certain borders or territories and also some nations that support the country. For example in Europe, the English nation appeared earlier before the emergence of the European nation and the modern country of England.

\subsection{The Level of the Building of the Nation-State}

Shamsul Amri Baharuddin (2012) has discussed in detail the process of the the building of a nation-state Malaysia through the historial sociology method. He divides the building of the country Malaysia to three main stages namely the Conflict Era (1945-1960), The Stable but Tensed Era (1961-1970) and the Social Unity Era (19712011).

\subsubsection{Conflict Era (1945-1960)}

In line with this era of the era of conflict, Malaysians are related to the various conflicts that emerge. After the Second World War, variosu conflicts have emerged. After the World War Two, the lives of the people are very poor. It can be the precursor to various problems. Starting with the domination of members of the communists known as Bintang Tiga who dominated the administration in Malaya for 14 days, whereas the shift of power ahs sacrificed a lot of lives be it the Malays or Chinese. The members of the communist were free to commit cruelty and carry out avengeful activities.

The second event is when Malayan Union declared on 1 April 1946 had caused a dissatisfaction among the Malays. Malayan Union had received an opposition from the Malays until it was terminated. The significant impact from this Malayan Union was the unification of the Malays until the United Malay National Organization (UMNO) was founded (Nazri Muslim and Azizi Umar 2017). Then, to resolve this issue, British has founded the Constitution of the Malaya Federation which received the responses from all parties which is the Malays represented by UMNO and the Malay Kings and Sultans. A momumental effort in easing the conflict between the races at the time was through the establishment of the Communities Liaison Committee (CLC) in 1949 comprising of leaders of the Malays, Chinese and Indians. This committee is thought to play an important role in cushioning the tension among the races at the time. From here, there is the ethnic bargaining or comprimise among the races used in the political analysis about Malaysia. Although Malaysia achieves independence on 31 August 1957, Malaysia was still in the state of Emergency that only ended on 31 July 1960. Thus, Malaysia was still in conflict although it was already independent.

\subsubsection{Stable but Still Tensed Era (1961-1970)}

This era was a critical era especially after the Emergency ended and the Cold War continued. The formation of the Malaysian Federation with the inclusion of Sabah, Sarawak and Singapore in 1963 became an important benchmark beginning with a country known as Malaysia. According to Shamsul Amri Baharuddin (2012), the success in including Sabah and Sarawak is a manifestation to the CLC founded in 1949 on the principle of ethnic tolerance. The Malayan government at the time was willing to agree with the 20-item demand from Sabah and 18 items from Sarawak in the aspect of their autonomy in managing their states. Indonesia was dissatisfied with the setting up of the Malaysian Federation and this country is regarded as a neo-colony. This confrontation was led by Soekarno whose government was said to have been influenced by the Indonesian Communist Party (PKI). An attack was later launched towards Malaysia. However, this confrontation came to an end when Soeharto was appointed as the President of Indonesia and he admitted on the existence of the Malaysian Federation.

The largest racial riot had taken place in two separate chains of events which is when Singapore was still in Malaysia on the 21 July and 3 September 1964. It had taken so many lives and thousands were arrested. This issue became fundamental to the removal of Singapore from Malaysia for constructing a stable country, Malaysia. Other than that, the 13 May 1969 brought upon the largest racial riot in Malaysia. It was the fundamental point for Malaysia to realise that there should be an effort towards social unity. Thus, various efforts have been made by the government top-down. Among the efforts is to set up the People's Negotiation Council, the National Unity Department, the National Principles and the New Economic Policy. Thus, the government began to make an effort in every policy implementation with the end goal is to produce national unity (Hazwani Che Ab Rahman, Abdul Latif Samian and Nazri Muslim 2018).

\subsubsection{The Social Unity Era (1971-2011)}

The Social Unity Era (1971-2011) was the era when there was a strong positive interaction between the society, 
the state and the market. Although it was fluctuating due to the global influence, Malaysia is still able to defend the social unity in the pluralistic society. Although there was an event like the Kampung Medan event in 2001 between the Malay and Indian ethnic groups, it has shown that the economic factor is an important indicator in ensuring the stability and harmony of the races.

Thus, Malaysia has to go back to the slogan unity in diversity and national unity including the vision to form a desired nation which is the Malaysian Nation. The capacity to accept diversity, produces the slogan like Malaysia Truly Asia, Unity in Diversity and Celebrating Diversity. Thus, through this era, unity is not an issue to the nationstate building. What remains to be a problem is the dominating racial attitude, suspicions and the lack of compromise among ethnic groups.

\section{The Challenge in the Formation of the Nation-State of Malaysia}

A harmonious ethnic relation is the key to the building of the nation-state. In the context of Malaysia that has diverse ethnic groups, It would be impossible for this country to be built if the ethnic relations cannot be managed properly. The building of a nation-state requires an attention towards the challenge in managing the existing diversity. The issue that often becomes the point of debate among the society would be the issue related to the constitution such as challenging the Social Contract. The Social Contract is an agreement that is not recorded when formulating the constitution involving Malays and the non-Malays with regard to citizenship status, the position of Islam, the special position of the Malays, the Malay Language and the Royal Institution. This is often raised especially when approaching the coming election that can lead to the conflict among the people. (Nazri Muslim 2020).

The history of the federal constitution drafting early stage shows the ethnic Malays, China and India have come together and work through the Social Contract in order to maintain unity. This is due to a variety of sensitive issues are raised that can lead to conflict among people of various ethnic groups such as the position of the Malays, the Malay language, Islam and the Malay Rulers and citizenship. Ethnic Malays, Chinese and Indians agreed matters involving Malays, Malay Language, Islam and the Malay Rulers and citizenship be preserved in the Federal Constitution. Similarly, after the entry of Sabah and Sarawak into Malaysia, for the sake of unity, the rights of the people of Sabah and Sarawak were preserved.

\section{The Constitution and the Building of a Nation-State Malaysia}

The discussion on the constitution and the building of a nation-state of Malaysia will be elaborated in several aspects like the concept of the constitution, the history of the constitution, ethnic cooperation and the Principles of the constitution. This aspect will explain about how the constitution serves as the main element of the building of a nation-state of Malaysia.

\subsection{The Concept and Development of the Constitution}

For a sovereign country, the constitution is the highest source of the law and every individual must abide by its integrity. Its existence serves as the guidance in arranging and coordinating the ruling of a country. In Malaysia, there is no one constitution that can overrule the supremacy of the Federal Constitution. Even all three government bodies refer to the doctrine of power segregation which is the legislative, the judiciary and executive or the Yang di-Pertuan Agong are subject to the Federal Constitution (Mohamed Suffian 1987). For example, the power of the legislation must be exercised following the restrictions imposed by the constitution. Meanwhile, the judiciary power must also be exercised following the restrictions imposed by the constitution. This is because the constitution clearly allocates under Article 4(1) that this constitution is the main law of the federation and any law endorsed after the independence and which opposes this constitution is considered void as far as the opposition goes.

The basis of the Federal Constitution begins with the declaration of the Malaya Federal Constitution on the $1^{\text {st }}$ of February 1948. According to this constitution, a British High Commissioner was placed under the Central Government as the highest ruler. Local people were represented through the Assembly Council and the Legislative Council in preparation for the self-government. Thus, when the Alliance won the 1955 General Election by dominating 51 out of 52 seats contested, a conference was held in London from 18 January to 6th February 1956. As the outcome, a commission named the Reid Commission was formed to formulate a new constitution for Malaya that is already free and independent (Nazri Muslim, Nik Yusri Musa dan Ahmad Hidayat Buang 2011).

The constitution of the Malaya Federation was formulated by Reid Commission established in 1956. It was led by Lord Reid and received 131 written memorandums and it had met from June to October 1956. This constitution becomes strong and practical and respected because it had asked for the suggestions and views from not only the political parties but also the public, individuals and Malay Royals. This justifies that the Federal Constitution has 
currently been getting the approval and positive response from all Malaysians.

During the formulation of the constitution, the Malay and non-Malays agreed upon several things that are important to the stability of the country in reference to the social contract. Through this social contract, the non-Malays were given citizenship rights that were lenient based on the jus soli principle. Meanwhile, the Malays were allocated in the constitution Islam as the federal religion, Malay language as the national language and their special position also the position of Malay Royals or what is called the traditional elements in the constitution (Nazri Muslim, Wan Zulkifli Wan Hassan, Jamsari Alias, Norazila Mat and Abdullah Ibrahim 2019). The basis of this contract, if it is accepted and understood, is for the process of the building of a nation-state can be achieved more easily. Yet, this issue is often raised and becomes the topic of debate among the general public.

\subsection{Constitution and Ethnic Relations}

In the context of ethnic relations in Malaysia, the agreement in the Social Contract should be better known as the Principles of the Constitution because the issues of Islam, the special position of the Malays and the Malay Language continue to be the conflict in the society. With the use of the term, it reflects the importance of this to be understood so that there is no dispute among the multiple ethnic groups in Malaysia and how different this is from the constitutions of other countries. To the Malays, the principle is essential and the mainstay of our daily lives such as the home building cannot be done if the main pillar is not erected.

The things thought to be profitable to the Malays in the Federal Constitution were balanced with other allocations that also gave a certain edge to the non-Malays. The determination of Islam as a federal religion was balanced with the allocation for freedom for every citizen to embrace and practise any religion in peace and harmony. The same applies to the Malay Language as the national language- it is also balanced with the allocation that no one can be prohibited from using, teaching or learning any other languages, except for official purposes. The same case applies to the determination of the special position of the Malays and Sabah dan Sarawak Bumiputera which is balanced with the allocation that the government cannot revoke, remove or erode the rights of other races (Nazri Muslim 2012).

Thus, traditional elements or The Principle of the Constitution should be brought into the discussion because it is an important factor to create the Malaysian identity and instill an understanding towards unity. It is also a social contract that has been agreed upon in formulating the constitution and it is needed for the stability and progress and it plays an important role in the constitution (Mohd Salleh 1985). These elements have long existed hundreds of years before the constitution was established in 1957 and the role is to stabilize the country's political system. This is stated in the Reid Commission Report stressing on the importance of the constitution to consider the historical, traditional, economic and social factors back in 1957.

Other than the role as the political stabiliser, the things involving the special position of the Malays, Islam and Malay Language and the Malay Kings' position are also protected from the Sedition Act and thought to be sensitive enough, and prohibited from being the public issues. This situation is added with several perceptions that are inaccurate but still become the principles and continue to be held by a large fraction of Malaysians (Haris 1990). These perceptions play on the feelings, thoughts and actions on the ethnic groups leading to some profound suspicions and doubts among the races. Among the perceptions are:

1) The country Malaysia is ruled by the Malays or the political power of this country is in the hands of the Malays.

2) The economic power in this country is in the Chinese hands or that all Chinese are rich.

3) All the Malays get special rights and enjoy the benefits from all government policies.

4) Racial unity is impossible to be achieved due to the difference in the religion, culture and race.

5) Most of the Malays are poor because they are lazy.

6) Most of the Chinese are rich because they are good at cheating in business.

7) The New Economic Policy is only profitable to the Malays.

8) Chinese in Malaysia are discriminated against by the Malays.

9) The Chinese and non-Malays have sworn undivided loyalty to this country.

10) The failure in the implementation of the economic policy in this country is caused by Chinese sabotage.

\subsection{Ethnic Cooperation During the Formulation of the Constitution}

With the introduction of the Malaya Federation, the cooperation between the Malays and non-Malays began to form. As an example, the establishment of the 1949 Communities Liaison Committee (CLC) comprising of various 
ethnic groups had tried to resolve some of the problems about the constitution, politics and economy that emerged following the groups' diverse requests. CLC is the first organization to have been established unofficially to discuss several issues like citizenship and the special position of the Malays also the education policy. Through this CLC, leaders of various ethnic groups discussed openly about the emerging issues and the solutions to them. Other than trying to get closer and working between ethnic groups, the CLC itself is thought of as a place for the representative for every ethnic group to talk about the different interests of the ethnic groups. Among the prominent figures that take part in the group are Dato' Onn Jaafar, Dato' Abdul Wahab Abdul Aziz, Tan Cheng Lock, C.C. Tan, E.E.C Thuraisingham and many others. However, it does not get a good response because the objective has been doubted by the Malays themselves, although it was a good start in forming the cooperation among ethnic groups in Malaya at the time.

The cooperation between ethnic groups continued when British had made a change of policy towards selfgovernment. In 1951, the Member System was introduced. Through this system, British had appointed several representatives of the citizens from the Malay Federation to become members in the Federal Work Meeting Council and later upgraded to ministers comprising of Malays, Chinese and Indians. It aims to give them the opportunity and training to the local leaders to get the experience to govern through democracy.

In 1951, The High Commission Deputy with the endorsement of the Kings and Sultans, had announced that it was to appoint a Federal Election Committee to look into the issues of the election to the federal Legislative Council. Thus, through several series of the election, close cooperation between ethnic groups will continue to be established.

In February 1952, the election in the Kuala Lumpur City Council was held and 12 seats were contested with UMNO and MCA forming an unofficial affiliation with both parties winning nine seats and the rest was dominated by IMP and independent candidates. However, this cooperation was not done with a clear planning from the leaders of UMNO-MCA. It was done between small leaders of UMNO-MCA Kuala Lumpur namely Dato' Razak Yahya and H.S. Lee who was disappointed with the treatment given by Dato' Onn Jaafar to him in Malaya Independence Party (IMP) that had put neglected the cooperation between MCA and IMP. H.S Lee had successfully named 6 candidates after giving UMNO a total of $\$ 500,000$ for the election expenditure and UMNO obtained 5 seats (Ramlah Adam 2003).

The victory in the election of the Kuala Lumpur City Council caused a Round Table Negotiation to be held between $\mathrm{UMNO}$ and MCA. The purpose was to find an understanding and cooperation between two largest ethnic groups in pursuing independence. Before that, UMNO placed the condition that MCA accept and acknowledge all the Malay rights and this was agreed by MCA. The Round Table Negotiation held on 3 February 1953 was attended by UMNO representatives comprising of Tunku Abdul Rahman, Tun Dr. Ismail, Saadon Zubir, Bahaman Shamsuddin and Syed Nasir Ismail. Meanwhile, MCA was represented by Tan Cheng Lock, H.S. Lee, Leong Yew Koh, S.M. Yong and T.H. Tan that led to the establishment of the Alliance. The formation of the Alliance shows the beginning of the collaboration era that was strong among the ethnic groups in Malaya as they were heading towards Independence through the sharing of power led by UMNO.

Thus, in the 1955 General Election, the Alliance contested by placing its candidates for all 52 constituencies, the National Party in 33 constituencies and PAS with 11 constituencies. If we look at the division of seats and candidates, clearly the Alliance Party led by UMNO had practiced the concept of power sharing through the division of seats in the 1955 election. Based on the voting strength, UMNO should have demanded not less than 90 percent from the total number of seats. Only a personal convincing from Tunku Abdul Rahman was successful in influencing the Malays to terminate their demand. This is because Tunku Abdul Rahman no longer fought for national Malays as highlighted in 1955 leading to the reduction in the number of UMNO seats (Ramlah Adam 2003). However, in the electoral manifesto, the parties in the Alliance swore to protect the special position of the Malays and defended the position of the Kings and Sultans as the constitutional heads in their respective states. This manifesto also acknowledges the existence of a serious problem raised by a number of foreign residents and how important it was to create a sense of unity and loyalty which is common for all ethnic groups.

In the selection of candidates, the Alliance had made a consideration about two things, namely racial considerations and harmony considerations. Upon the latter, 17 from 52 candidates of the Alliance were non-Malays although in reality only two constituencies had non-Malay voters as the majority. Clearly, the Alliance believed that the thinking pattern and the method of voting was not racially-oriented in 15 constituencies. However, this risk is an essential sacrifice to be committed by all the races.

In the 1955 General Election, the Alliance had won 51 from 52 seats contested and PAS won a seat which is in Kerian, Perak. This first general election shows that the Alliance got $80 \%$ of votes and the majority of votes from 
the Malay and non-Malays. All the non-Malay candidates from the Alliance had won with large number of votes, although a lot of them had contested in areas with more Malay voters, and they had gone against the non-Malay candidates. In that election, there were 1.28 million of names in the registration and more than 1 million people had cast their votes. From this figure, $84 \%$ were the Malays, $11 \%$ Chinese and 5\% Indians and others (Smith, T.E. 1955).

A stronger cooperation between the Malay and non-Malays continued to form when the British decided that independence would only be granted if the people of this country united and cooperated. If we look back, before the election, MCA and MIC were not politically oriented, but more to taking care of the welfare and interests of their own groups. However, when UMNO invited and worked together with MCA and combined and formed the Alliance, this action had demonstrated their openness and that they were willing to share the power and tolerance to ensure unity among the races.

Here, the issue of independence has transcended racial boundaries and transformed a segregated society to a united one. It enabled them to put aside the narrow perceptions about racism and work towards demanding for independence from the colonial power. After negotiating with the High Commissioner, Donald MacGillivray, Tunku had formed a Cabinet comprising of a composition of six Malays, three Chinese and an Indian. The selection of this Cabinet shows a good cooperation with the appointment of three Chinese and an Indian to give an ethnic balance that is more accepted in the Legislative Council. The effort to construct a nation-state during this time worked smoothly because it gained the support from the society.

\subsection{The Analysis of Ethnic Cooperation When Formulating the Constitution}

Looking at the sequence of events towards getting the independence, every ethnic in Malaysia plays their respective roles and involvement in the demand for independence. This is through the establishment of the 1949 Ethnic Relations Committee that motivated the effort towards creating harmony and collaboration among the races. This was followed by the introduction of the 1951 Member System aiming to give an exposure and training to the local leaders in the country's administrative affairs, a country comprising of leaders from various ethnic backgrounds. The understanding and cooperation become more solid when UMNO and MCA unofficially collaborated in the Kuala Lumpur City Council Election that led to the Round Table Negotiation three times in the effort to have an agreement, to gain respect and to collaborate to demand for independence until the Alliance was established in 1953.

There is something interesting during the 1955 Federal Election where Malays' racial sentiment was rejected. If the Malays were racist, they could set up a Malay government and formulate a constitution for the independent Malaya. Surely the constitution would ensure the power of the Malays in a continuous manner. In July 1954, the Alliance and British agreed to have a Federal Legislative Council with 98 members- 52 of them selected and 46 appointed. From the 46 members appointed, five of them were nominated by the political party that gained a majority in the election. In the 1955 election, Malay voters made up the majority of 50 out of 52 electoral constituencies because $84 \%$ were Malay voters from all over the country. Other than that, 9 members from the 46 members appointed comprised of the Malays which is 9 Chief Ministers or Menteri Besar (Zainal Abidin Abdul Wahid 2001).

Thus, if the Malays adopt a racist attitude, they could win the 50 seats contested and they could nominate five more Malay members from the 46 members appointed. Thus, the Malays will get 65 members including a Native representative. These 65 members are more than two third the total number of members in the Legislative Council. This means the Malays have enough majority to amend the constitution or formulate a new constitution that can be advantageous to the Malays. However the Malays do not use this opportunity to keep the interests involving the relationship and unity among the ethnic groups. The sacrifice of the Malays at the time was great which spurred the spirit of tolerance among the ethnic groups.

Based on harmony and tolerance, the principle of jus soli was accepted in terms of citizenship. The same applies to the issue concerning the special position of the Malays, it was addressed well. No one questioned why the Malays were to be given the protection so they were able to achieve the same economic level with other groups. Tunku Abdul Rahman himself had declared that in this issue, it will not be revoked. Next, the memorandum proposes that part of the land, the scholarships, the position in the public services and business permits must be granted especially to the Malays without affecting or reducing the rights and opportunities available for the nonMalays. (Nazri Muslim 2019).

Issues related to the Malays' special rights also invited a hot debate. UMNO had treated with cynicism the proposal of the Commission to make a full revision of all the items in 1972 which is 15 years after the independence. According to the Commission, the Malay privileges must be acknowledged with regard to the Malays' land 
reserves, the number of non-Malays entering public services, through the letter of approval or license and also about study incentives, financial aids, and other assistance for education. The special considerations given to the Malays must be retained but cannot exceed the allocations. The Commission suggested that this is revised after fifteen years (Nazri Muslim 2020).

With regard to Islam, the Alliance agrees that religion for the Federation must be Islam. The admission of this policy will not impose any prohibition to non-Muslim citizens to embrace and practice their own respective religion and not meaning that the country is not a secular state (Ibrahim Mahmood 1981). The demographic position of Malaya at the time due to the influx of foreign immigrants and the number of non-Malays that is felt to be a threat to the Malays also the commitment to Islam are the bargaining factor voiced by UMNO with regard to Islam as the Federal Religion.

\subsection{Post-Malaysia Constitution}

The formation of Malaysia in 1963 has brought along another dimension to the ethnic relations in Malaysia. With the inclusion of Sabah and Sarawak, the position of Bumiputera Ethnic in both states is given the same status with the Malays, where they were also included in Article 153. However, the allocation does not give any license to oppress other races because the special rights of the Malays and Sabah and Sarawak Bumiputera have to be protected by way of not refuting the valid position of the ethnic group.

The Malaysian Agreement sealed in 1963 is an agreement between leaders of Malaya, Sabah and Sarawak. It is better known as the Twenty Articles and Eighteen Articles containing the demands of Sabah and Sarawak that agreed to join Malaysia. Among the content of both sets of Articles is with regard to the immigration, language, finance and the special rights of Sabah and Sarawak Bumiputera. It can be referred in List II and List III so with regard to the additional allocation for Sabah and Sarawak. The position of Sabah and Sarawak in the constitution is protected by the power of the Yang di Pertua Negeri, where the amendment can only be done if they had given their agreement. This means that the parliament cannot amend the special position of Sabah and Sarawak Bumiputera. This resembles the role of the Royal Council with regard to the position of the Malays (Nazri Muslim 2020).

\subsection{The Principles of the Federal Constitution}

The Principles of the Constitution or traditional elements refer to Islam, Malay Language, the Malays and Malay Sultans and Kings in the constitution. The word 'tradition' carries a few meanings. Tradition means the shift and continuity from one generation to another. This reflects the tradition of portraying the history, the culture and the understanding of a nation and the society. In the context of politics and the constitution, what is implied as the traditional system refers to the system that exists before the arrival of the modern era, which is a system which validity relies on religion and its other original values.

On one hand, the traditional institutions seem to have their own strength, something that looks like it stems outside the system and the framework of the constitution. This is because the history, identity and continuity that are said to be able to function as the soul and spirit of a society are not included in the issues of democracy. The traditional elements are very important to be discussed because it is the main factor to create the Malaysian identity and instill the understanding towards the unity and the building of the nation-state.

The elements of principals are also the prerequisite and the consensus accepted by both the Malays and non-Malays. This means that the special rights of the Malays, Islam being the Federal religion and Malay Language accepted as the national national languageare the prerequisites for the citizenship acceptance by non-Malay ethnic to be retained and solidified. This shows that previous leaders have accepted a formula to resole the issue that exists without involving any inter-racial conflict in Malaya at the time.

For example, other than implementing the power allocated by the Constitution, Yang di-Pertuan Agong is also the symbol of unity of the Malaysian society comprising of various ethnic groups. Malays, Chinese, Indians and other races regard the Majesty as the preserver of the interests and hope for every ethnic group in Malaysia. This is because under the Constitution it is allocated that it is the responsibility and mandate of the Yang di-Pertuan Agong to preserve the special privilege of the Malays and the Sabah and Sarawak Bumiputera and other valid interests of other races. The same applies to the Royal Council who have the power in amending the allocation regarding citizenship. The mandate and responsibility are two extremely difficult things because issues like religion and the special position of the Malays and citizenship often become the polemic in the multi-ethnic society. If the issues are not handled properly, it can affect the stability of the country. Although his function as a symbol of unity and continuity is rather passive and non-controversial, the assurance that highlights The Majesty's immunity is essential to prevent him from being seen as a tool of the government. 
Yang di-Pertuan Agong is also an epitome of justice and equality because it is him who appoints all the judges of the Federal Court and the High Court upon the advice of the Prime Minister after negotiating with the Royal Council. Negotiations also have to be done with regard to the appointment of the national auditor, chairman and members of the Delection Commission and Education Service Commission. These positions are important in upholding the rights of the people by taking a neutral stance which is not taking sides with any party or even the government itself. He is also regarded as the Head of Sovereignty or Tunggak Kehormatan as he is given the power to confer respect, medal and ward to certain people who have served the country well regardless of their ethnic groups.

Yang di-Pertuan Agong and the Royal Council are the elements of the Principles that are very important in Malaysia. To the Malays, they are the beacon of hope and the symbol of unity among the people of various ethnic groups. This is because they are not chosen through political means and they are not excepted from politics. These are among the reasons that enable the royal institution to have the potential to play its part without imposing any terms and conditions as determined by political parties. For political parties however, all of their decisions are bound by party-oriented sentiments and considerations. The Yang di-Pertuan Agong is one of the institutional constitutions who is Malay in nature, Muslim highly important because the Prime Minister, the Cabinet and the Parliament are not necessarily designated for Malays. Symbolically, Yang di-Pertuan Agong acts as the authoritative power and the power granted by the Malay states to the central authority (Nazri Muslim and Azizi Umar 2017).

It has to be explained as well that the allocation for Islam and the Malays does not concentrate only on certain matters. Even more so, the allocations leave an impact or implication to the ethnic relations in Malaysia. It shows that the issues of Islam and the Malays will continue to be an issue or conflict in the society if they are not handled well (Nazri Muslim, Wan Zulkifli Wan Hassan, Jamsari Alias, Norazila Mat and Abdullah Ibrahim 2019). This is a challenge towards the building of a nation-state.

The same goes with the understanding about the rationale behind the Malay Language being the national language. The main purpose behind this is to fulfil the need to unite various ethnic groups so that it becomes a united country through a common language, which is the Malay Language that has become the medium of instruction in this country since the Melaka Sultanate Era. This is because, during the formulation of the constitution, previous leaders have decided that an independent state cannot continue to use English as the official language to unite its people especially when the state is pluralistic. Thus, the non-Malays need to accept the Malay Language as more than just a national language, and at the same time they should accept the rights of the non-Malays to use and learn their mother tongues as dictated in the constitution.

The acceptance of traditional elements in the constitution such as the position of the Malays, Malay, Islam and the Malay Rulers show any ethnic Malays, Chinese and Indians are willing to compromise for the sake of developing the country. This is because for ethnic Malays, the special position of the Malays, the Malay language, Islam and the Malay rulers had long been held by Malays in everyday life. Without this cooperation it is very difficult for Malaysia to develop in harmony.

\section{Conclusion}

In the world today, the building of nation-state, the issue of the rights of the minority, ethnic and basic human rights, have become issues all over the world. Every country uses several approaches to address these be it through military strength or through the constitution (Lakshman Marasinghe 1993). In Malaysia, the approach adopted is the constitutional approach. This is because the Federal Constitution is the outcome of the bargaining process between the the three largest ethnic groups - Malays, Chinese and Indians through UMNO, MCA and MIC. The process has created a balance of interest among the races in the Federal constitution today. In 1957, during the formulation of the constitution, the Malays and non-Malays uphold their interests for such an independent country. The Malays not only are concerned about their socio-economy, but also about their position. However, this does not stop every ethnic group from working together and finally agreeing to several issues such as the lenient citizenship, Islam as the official religion, the status of the Malay Language and the Malay privileges as discussed earlier. The building of a nation-state requires an overall participation from all members of the society and the government machinery. Malaysians need to understand and apply this concept so that the process of building becomes stronger. A common value needs to be created and appreciated by all citizens of Malaysia as dictated in the constitution in enabling the building of a nation-state (Nazri Muslim. 2012).

\section{References}

Abdul, R. E. (2015). Negara bangsa: Proses dan perbahasan. Ed.ke-2. Bangi, Malaysia: Penerbit UKM. 
Chambers' Encyclopedia. (1973). Chicago: William Benton Publisher.

Chew, F. P. (2006). Pembentukan Negara Bangsa Melalui Pendidikan Sastera. Jurnal Pengajian Melayu, 17, 136168.

Haris, M. J. (1990). Etnik, Politik dan Pendidikan. Kuala Lumpur: Dewan Bahasa dan Pustaka.

Hassan, A. (2004). Kesusasteraan dan Pembinaan Negara Bangsa. Dlm. Shaiful Bahri Md. Radzi \& rakan-rakan. Sastera dan Pembinaan Negara Bangsa. Prosiding Seminar Antarabangsa Kesusasteraan Melqyu (SAKM) VIII, hlm.1-13. Bangi: Universiti Kebangsaan Malaysia.

Hazwani, C. A. R., Abdul, L. S., \& Nazri, M. (2018). Unity of Science, Religion and Language in the Education System: Selected Malay Muslim Scientists Responses. International Journal of Civil Engineering and Technology, 9(2), 548-564.

Ibrahim, M. (1981). Sejarah Perjuangan Bangsa Melayu. Kuala Lumpur: Pustaka Antara.

Lakshman, M. (1993). Ethnic Conflicts and Constitutional Reform. Syarahan Perdana Fakulti Undang-Undang, University Windsor.

Lee, K. H. (2005). Writing Malaysia's Contemporary History. In Wang G. (Eds.), Nation-building: Five Southeast Asian Histories (hlm. 163-190). Singapore: Institute of Southeast Asian Studies. https://doi.org/10.1355/9789812305503-009

Malaysia. (1972). Perbahathan Parlimen Mengenai Rang Undang2 Pindaan Perlembagaan 1971. Kuala Lumpur: Jabatan Penerangan Malaysia.

Means, G. P. (1976). Malayan Politics. London: Stroughton and Hodder.

Mohamad, A. O. D. (2004). Legitimasi Mitos dalam Pembinaan Negara Bangsa. Dlm. Shaiful Bahri Md. Radzi \& rakan-rakan. Sastera dan Pembinaan Negara Bangsa. Prosiding Seminar Antarabangsa Kesusasteraan Melqyu (SAKM) VIII, hlm.431-447. Bangi: Universiti Kebangsaan Malaysia.

Mohamed, S. H. (1987). Mengenal Perlembagaan Malaysia. Dewan Bahasa dan Pustaka. Kuala Lumpur.

Mohd, S. A. (1985). Unsur-Unsur Tradisi Dalam Perlembagaan Malaysia. Kuala Lumpur: Dewan Bahasa dan Pustaka.

Mohd, S. A. (2014). MPU3113 Hubungan Etnik. Kuala Lumpur: Open University Malaysia.

Nazri, M. (2012). Implikasi Peruntukan Islam dan Orang Melayu Dalam Perlembagaan Persekutuan Terhadap Hubungan Etnik di Malaysia. Kemanusiaan: The Asian Journal of Humanities, 19(2), $19-62$.

Nazri, M. (2019). Socializing the constitution: Malaysian national agenda. Asian Social Sciences, 15(11), 35-41. https://doi.org/10.5539/ass.v15n11p35

Nazri, M. (2020). Islam Dan Melayu Dalam Perlembagaan: Tiang Seri Hubungan Etnik Di Malaysia. Edisi Kedua. Bangi: Penerbit UKM.

Nazri, M., \& Azizi, U. (2017). Malay Royal Institution According to the Federal Constitution within the Context of Ethnic Relations in Malaysia. Akademika, 87(1), 35-48. https://doi.org/10.17576/akad-2017-8701-03

Nazri, M., Nik, Y. M., \& Ahmad, H. B. (2011). Hubungan Etnik Di Malaysia Dari Perspektif Islam. Kajian Malaysia, 29(1), 1-28.

Nazri, M., Wan, Z. W. H., Jamsari, A., Norazila, M., \& Abdullah, I. (2019). Malaysia Federal Constitution from Constitutional Sociology Contexts. Journal of Engineering and Applied Sciences, 14(11), 3761-3770. https://doi.org/10.36478/jeasci.2019.3761.3770

Ramlah, A. (2003). Sejarah Perkembangan Pilihanraya Era Pra-Merdeka 1955. Melaka: Institut Kajian Sejarah dan Patriotisme.

Shamsul, A. B. (2012). Modul Hubungan Etnik edisi kedua. Bangi: Institut Kajian Etnik, UKM.

Smith, T. E. (1955). Report on the First Election of Members of the Legislative Council of the Federation of Malaya. Kuala Lumpur: Government Printer.

Tham, S. C. (1983). Education and Nation-Building in a MultiEthnic Society: The Case of Malaysia and Singapore. Kertas Kerja. Seminar Modeninasi dan Keperibadian Budaya Bangsa. 10-12 Januari. Persatuan Sains Sosial Malaysia.

Zainal, A. A. W. (2001). Bahasa, Pendidikan dan Pembangunan. Kuala Lumpur: Dewan Bahasa dan Pustaka. 
Zulhilmi, P., \& Rohani, A. G. (2003). Kenegaraan Malaysia: Isu-isu dalam Pembinaan Negara. PTS Publication.

\section{Copyrights}

Copyright for this article is retained by the author(s), with first publication rights granted to the journal.

This is an open-access article distributed under the terms and conditions of the Creative Commons Attribution license (http://creativecommons.org/licenses/by/4.0/). 